\title{
The impact of electronic cigarette liquids on human gingival cell viability - a preliminary in vitro study
}

\author{
Wpływ elektronicznych papierosów na żywotność ludzkich \\ fibroblastów dziąseł - wstępne badania in vitro \\ ${ }^{1}$ Department of Medical Chemistry, Medical University of Gdańsk \\ 2 Department of Periodontology and Oral Mucosa Diseases, Medical University of Gdańsk \\ ${ }^{3}$ Department of Orthodontics, Medical University of Gdańsk
}

DOI: http://dx.doi.org/10.20883/df.2016.2

\begin{abstract}
Introduction. E-smoking is a new phenomenon, not only because of the opportunity for limiting or abandoning smoking, but also because it may become an introduction to traditional smoking, especially by young people, and addiction to nicotine. At the moment it is impossible to assess the advantages of e-smoking and the risk of undesirable effects, or even the toxic influence on the oral cavity tissues, due to the complexity of the phenomenon and the very few accurate clinical and laboratory studies.

Aim. The aim of the study was the impact of electronic cigarette (EC) liquids on human gingival cell (HGF-1) viability in an in vitro study.

Material and methods. Commercially available EC liquids with 11 and $24 \mathrm{mg} / \mathrm{mL}$ nicotine contents and different flavours were tested. Cytotoxicity on HGF-1 was evaluated after 24 and $48 \mathrm{~h}$ of exposure to EC liquids in concentrations of 0.1 and $1 \%$.

Results. Among all the tested EC liquids only Mint-flavoured ones have a harmful effect on HGF-1 cells in a time-dependent manner. No statistically significant difference was found between EC liquids with 11 and $24 \mathrm{mg} / \mathrm{mL}$ nicotine contents.
\end{abstract}

Conclusions. Our data indicated that flavour additives in EC liquids may exert biological effects on oral cells.

Keywords: electronic cigarettes, smoking, cytotoxicity.

\section{Streszczenie}

Wprowadzenie. Palenie e-papierosów jest nowym zjawiskiem. Może być nie tylko szansą ograniczenia bądź rzucenia palenia, ale stanowi również zagrożenie jako wstęp do tradycyjnego palenia (szczególnie u ludzi młodych) i uzależnienia od nikotyny. W chwili obecnej z powodu złożoności tego zjawiska oraz niewielu badań klinicznych i laboratoryjnych nie jest możliwe porównanie korzyści wynikających z e-palenia z ryzykiem niepożądanych efektów, wśród których wymienia się niekorzystny wpływ na tkanki jamy ustnej.

Cel. Celem pracy była ocena oddziaływania liquidów do e-papierosów (EC) na żywotność ludzkich fibroblastów (linii komórkowej HGF-1) w warunkach in vitro.

Materiał i metody. Badaniem objęto dostępne na polskim rynku liquidy o różnych smakach z zawartością nikotyny 11 i $24 \mathrm{mg} / \mathrm{ml}$. Cytotoksyczność wobec linii komórkowej HGF-1 była oceniana po 24 i 48 godzinach od ekspozycji na liquidy w stężeniu od 0,1 do $1 \%$.

Wyniki. Wśród wszystkich badanych liquidów tylko miętowy wykazał szkodliwy wpływ na komórki HGF-1 w sposób zależny od czasu. Nie stwierdzono statystycznie istotnej różnicy między liquidami do e-papierosów o zawartości nikotyny 11 i $24 \mathrm{mg} / \mathrm{ml}$.

Wnioski. Liquidy do e-papierosów mogą wykazywać biologiczny wpływ na fibroblasty w obrębie jamy ustnej.

Słowa kluczowe: elektroniczne papierosy, palenie, cytotoksyczność.

\section{Introduction}

E-smoking is a new phenomenon. Although it is an opportunity for limiting or abandoning smoking, it may also become an introduction to traditional smoking. Young people are especially in danger [1-8]. At the moment it is impossible to assess the advantages of e-smoking and the risk of undesirable effects, or even the toxic influence on the oral cavity tissues [9] due to the complexity of the phe- nomenon and the very few accurate clinical and laboratory studies.

Habitual smokers have worst clinical results in nonsurgical and regenerative periodontal treatment. Among the negative influences of nicotine on the periodontium the following may occur: an increase in the quantity and quality of periopathogenic subgingival biofilm, and the immunomodulation of the host reaction; e.g. an intensification of the de- 
structive processes in the connective tissue and the bone as well as a deficiency in the healing process [10-12]. Accordingly, nicotine is considered as the main pathological factor in certain precancerous states of the oral cavity mucosa, such as the leukoplakia and the neoplasms [13].

Minimizing nicotine intervention becomes an important part of any prophylactic and therapeutic action. Nicotine replacement therapy may include adhesive plasters, tablets or chewing gum with nicotine. In recent years attention has been focused on so-called electronic cigarettes containing nicotine [14-17]. E-smoking is still not a well-known phenomenon, and it may carry the risk of unexpected side effects or even toxic influences [17].

According to the World Health Organization, tobacco smoking is one of the most serious health threats in the world. It concerns not only general health problems, such as cardiovascular disorders or breathing system disorders, but also oral cavity health including periodontal and oral mucosa conditions.

Many studies indicate that smokers are choosing ECs for the same reasons as other nicotine substitutes - to limit their smoking and to reduce the symptoms from stopping $[9,15,18,19]$. The unanswered question is whether the regular use of e-cigarette liquids is free of risks to the health?

\section{Aim}

The aim of the study was to investigate the impact of electronic cigarette liquids on human gingival cell viability in an in vitro study.

\section{Material and methods}

\section{E-cigarette refill fluids}

All the fluids are popular and easily available to e-cigarette users in local shops in Poland. Seven bottles of refill fluids containing various flavourings (Pepper Mint, Fresh Ice Mint, Juicy Cherry, Very Strawberry, Black Tea, Black Currant, Natural Tobacco) in two nicotine concentrations (11 and 24 $\mathrm{mg} / \mathrm{mL}$ ) were evaluated (Table 1).

\section{Cell culture}

An HGF-1 cell line was obtained from the American Type Culture Collection (ATCC-HBT-55) and maintained as a monolayer culture in T-75 cm2 tissue culture flasks. The cells were grown in Dulbecco's Modified Eagle's Medium (DMEM, Sigma Aldrich), a high glucose medium $(4.5 \mathrm{~g} / \mathrm{L})$ containing sodium pyruvate $(110 \mathrm{mg} / \mathrm{L})$, and supplemented with $10 \%$ fetal bovine serum, $6 \mu \mathrm{g} / \mathrm{mL}$ penicillin- $\mathrm{G}$, and $10 \mu \mathrm{g} / \mathrm{mL}$ streptomycin. The cells were maintained at $37^{\circ} \mathrm{C}$ in a humidified atmosphere of $95 \% \mathrm{O} 2,5 \%$ CO2 [20]. When confluent, the cells were detached enzymatically with trypsin-EDTA and sub-cultured into a new cell culture flask. The medium was replaced every 2 days.

\section{Cell exposure}

The concentrations of refill fluids used in the experiments were carefully chosen according to the results obtained from preliminary experiments and literature data. The e-cigarette refill fluids were diluted to appropriate concentrations in a serum free (SF) cell culture medium and filtered through a 0.22 $\mu \mathrm{m}$ membrane filter at the time they were added to the cells. The HGF-1 cells were then incubated with the refill solutions $(0.1 \%$ and $1.0 \%$, final concentration of nicotine: 11,$110 ; 24,240 \mu \mathrm{g} / \mathrm{mL}$, respectively) for 48 hours. The concentration of refill fluids was based on preliminary data obtained for concentrations of $0.001 \%, 0.01 \%, 0.1 \%, 0.5 \%$ and $1.0 \%$. Control cells were incubated with the same volume of SF cell culture medium (DMEM).

\section{Cytotoxicity of e-cigarette refill fluids evaluation - MTT assay and cellular morphology study}

The HGF-1 cells were seeded in triplicate at a density of $2 \times 104$ cells $/ 100 \mu \mathrm{L}$ of cell culture medium into a 96-well. The next day, CRL-2014 cells were exposed to different concentrations of e-cigarette refill fluids as above for 24 and 48 hours. This assay evaluates mitochondrial activity (assesses cell growth and cell death) and is performed by adding a premixed optimized dye solution to the culture cells. Absorbance was recorded at $570 \mathrm{~nm}$ (FLUOstar OPTIMA). Results from the treatment groups were calculated as a percentage of control values (unexposed cells) according to the following equation: $\%$ of viability $=$ (experimental absorbance [abs] 570 $\mathrm{nm}$ of exposed cells - background of experimental abs $570 \mathrm{~nm} / \mathrm{abs} 570 \mathrm{~nm}$ of unexposed cells) $\times 100$. Absorbance values were corrected for background (refill fluid blank used for each concentration).

The morphology of HGF-1 cells in the presence of EC fluids was visualized by a light microscope at 100x magnification (ALTRA20 microscopy and CelIA Acquisition software, Olympus, Japan). Control cells were unexposed to EC fluids.

The experimental results were expressed as mean \pm SD for the triplicate determination of 3-4 separate experiments. The results were analysed using oneway ANOVA and Tukey's post hoc test with a p value $<0.05$ being considered statistically significant.

\section{Results}

After an incubation time of $24 \mathrm{~h}$ none of the tested EC liquids exerted a statistically significant cytotoxic effect on HGF-1 cells (Table 1).

After $48 \mathrm{~h}$ of exposure, among all the tested liquids, only Mint EC fluids caused a marked reduction in HGF-1 cells viability. Compared to Fresh Ice Mint-flavoured liquids, the Pepper Mint-flavoured liquids were observed to exert a stronger cytotoxic effect on HGF-1 cells. The content of nicotine did not significantly influence the cytotoxicity of EC liquids in HGF-1 cells (Table 1). Significant morphological changes in HGF-1 cells were observed after 48 h HGF-1 exposure to Mint-flavoured EC 
(Pepper Mint, Fresh Ice Mint). These were characterized by cell shrinkage and irregular shapes when compared with control cells (Figure 1).

The phase-contrast micrographs were indicative of cell death induced by Mint-flavoured EC because HGF-1 cells detached from the cell culture dish after exposure to EC liquids.

\section{Discussion}

ECs are relatively new products and it is still not clear what influence EC refill fluids have human oral cells. This study shows that EC refill fluids demonstrated harmful effect on human gingival fibroblast cells in a time- and flavour-dependent manner. Behar et al. [21] proved that flavourings in refill fluids are linked to cytotoxicity in human embryonic stem cells, human pulmonary fibroblasts and mice neural stem cells. It has been found that among all the tested flavours only mint (Fresh Ice Mint and Pepper Mint) reduced HGF-1 cell viability. Additionally, the Pepper Mint flavoured liquid is observed to be much more cytotoxic than Ice Mint. Also, Wil-

Table 1. The impact of e-cigarette liquids on HGF-1 cell viability

Tabela 1. Wpływ liquidów do e-papierosów na żywotność linii komórkowej HGF-1

\begin{tabular}{|c|c|c|c|c|}
\hline \multicolumn{5}{|c|}{ Viability of HGF-1 cells (\%) } \\
\hline \multirow[t]{3}{*}{ EC liquid } & \multicolumn{4}{|c|}{ Concentration of e-cigarette liquids (\%) and time of incubation (h) } \\
\hline & \multicolumn{2}{|c|}{$0.1(\%)$} & \multicolumn{2}{|c|}{$1(\%)$} \\
\hline & $24 \mathrm{~h}$ & $48 \mathrm{~h}$ & $24 \mathrm{~h}$ & $48 \mathrm{~h}$ \\
\hline Control & $98.6 \pm 6.1$ & $97.3 \pm 4.8$ & $98.6 \pm 6.1$ & $97.3 \pm 4.8$ \\
\hline Very Strawberry* & $96.5 \pm 6.4$ & $98.9 \pm 7.6$ & $92.6 \pm 7.7$ & $81.4 \pm 7.9$ \\
\hline Very Strawberry** & $91.3 \pm 8.1$ & $90.8 \pm 8.5$ & $90.1 \pm 8.6$ & $83.6 \pm 5.0$ \\
\hline Fresh Ice Mint * & $98.2 \pm 4.2$ & $76.1 \pm 6.5^{\#}$ & $87.4 \pm 7.1$ & $69.1 \pm 7.1^{\#}$ \\
\hline Fresh Ice Mint ** & $97.8 \pm 5.9$ & $70.9 \pm 4.1^{\#}$ & $82.6 \pm 5.3$ & $64.3 \pm 6.4^{\#}$ \\
\hline Natural Tobacco * & $98.3 \pm 6.3$ & $90.3 \pm 6.4$ & $94.2 \pm 9.2$ & $87.2 \pm 9.1$ \\
\hline Natural Tobacco ** & $93.1 \pm 7.9$ & $87.4 \pm 5.9$ & $87.3 \pm 9.6$ & $80.9 \pm 7.3$ \\
\hline English Black Tea * & $91.6 \pm 3.8$ & $86.3 \pm 6.0$ & $89.4 \pm 7.4$ & $83.5 \pm 4.8$ \\
\hline English Black Tea ** & $96.2 \pm 8.2$ & $87.7 \pm 4.8$ & $88.2 \pm 4.2$ & $81.2 \pm 6.6$ \\
\hline Black Currant * & $97.2 \pm 5.8$ & $94.1 \pm 9.1$ & $95.1 \pm 5.9$ & $83.1 \pm 7.1$ \\
\hline Black Currant ** & $94.3 \pm 7.3$ & $93.4 \pm 8.3$ & $90.4 \pm 6.8$ & $81.7 \pm 8.9$ \\
\hline Pepper Mint ${ }^{\star}$ & $97.9 \pm 4.8$ & $44.6 \pm 3.2^{\#, \mathrm{a}}$ & $89.7 \pm 9.0$ & $37.2 \pm 3.4^{\#, a}$ \\
\hline Pepper Mint ${ }^{\star \star}$ & $90.6 \pm 4.1$ & $38.1 \pm 2.1^{\#, \mathrm{a}}$ & $86.2 \pm 8.2$ & $30.9 \pm 4.1^{\#, a}$ \\
\hline Juicy Cherry* & $97.8 \pm 9.1$ & $93.8 \pm 8.6$ & $98.0 \pm 4.1$ & $90.7 \pm 8.3$ \\
\hline Juicy Cherry ${ }^{* *}$ & $93.2 \pm 6.3$ & $97.9 \pm 5.3$ & $99.4 \pm 6.2$ & $88.6 \pm 6.4$ \\
\hline
\end{tabular}

* - $11 \mathrm{mg} / \mathrm{mL}$ nicotine; $24 \mathrm{mg} / \mathrm{mL}$ nicotine

${ }^{* *}-p<0.001$ compared with control

$a-p<0.001$ Pepper Mint-flavored EC compared with Fresh Ice Mint-flavored EC

(A) Control

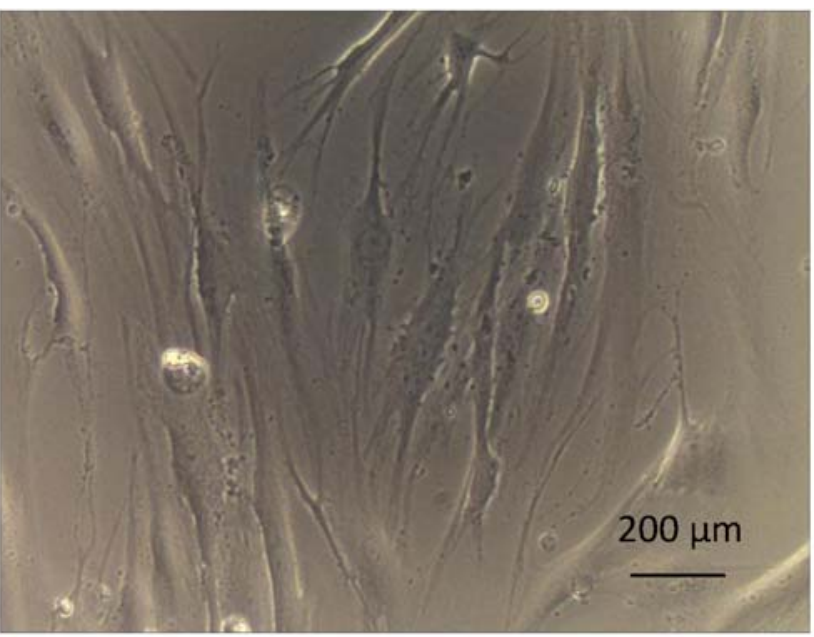

(B) $0.1 \%$ Pepper Mint, $11 \mathrm{mg} / \mathrm{mL}$ nicotine

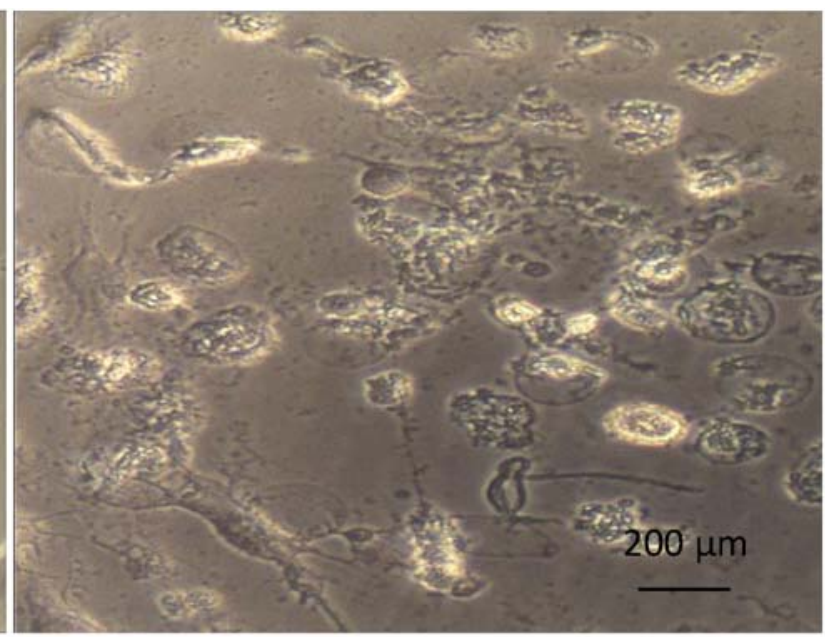

Figure 1. Morphological changes in HGF-1 cells exposed to $0.1 \%$ Mint-flavoured EC liquid with $11 \mathrm{mg} / \mathrm{mL}$ nicotine for a period of $48 \mathrm{~h}$ followed by phase-contrast microscopy; $(\mathrm{B})$ shows cell death as compared with untreated control cells (A) $($ bar, $200 \mu \mathrm{m})$

Rycina 1. Morfologiczne zmiany obserwowane w mikroskopie kontrastowym w linii komórkowej HGF-1 eksponowanej na $0,1 \%$ miętowy liquid do elektronicznych papierosów z zawartością $11 \mathrm{mg} / \mathrm{ml}$ nikotyny w okresie $48 \mathrm{godzin}$. (B) komórki uszkodzone w porównaniu z komórkami kontrolnymi, nie eksponowanymi na liquid miętowy (A) (bar, 200 m) 
lershausen et al. [22] observed that the addition of menthol may lead to a reduction in the proliferation rate of human periodontal ligament fibroblasts. On the other hand, a 13-week smoke inhalation study indicated that the addition of menthol to tobacco had no effect on the biological responses normally associated with the inhalation of cigarette smoke in rats [23]. According to studies performed by the tobacco industry, both menthol and non-menthol cigarette smoke have similar levels of cytotoxicity [24-26]. Menthol is a very popular tobacco flavouring because it masks the bitter taste of cigarette smoke [27]. What is important, though, is that Lmenthol as a cigarette additive may promote smoking initiation and nicotine addiction [27]. However, currently it has been found that flavour additives do attract people, especially the young, to electronic cigarettes $[28,29]$.

In conclusion, the authors have found that flavour additives to EC liquids exerted a biological inhibiting effect on oral HGF-1 cells in a flavour- and time-dependent manner rather than the nicotine content.

Further epidemiological, clinical and molecular research linked to the present study is recommended.

\section{Acknowledgements}

\section{Conflict of interest statement}

The authors declare that there is no conflict of interest in the authorship or publication of contribution.

\section{Funding sources}

There are no sources of funding to declare.

\section{References}

[1] Cho JH, Shin N E, Moon SS. Electronic cigarettes smoking experience among adolescents. J Adolesc Health. 2011;49:542-548.

[2] Durmowicz EL. The impact of electronic cigarettes on the paediatric population. Tob Control. 2014;23:41-46.

[3] Goniewicz ML, Gawron M, Nadolska J, Balwicki Ł, Sobczak A. Rise in Electronic Cigarette Use Among Adolescents in Poland. J Adolesc Health. 2014;55:713-715.

[4] Goniewicz ML, Zielińska-Danach W. Electronic cigarette use among teenagers and young adults in Poland. Pediatrics. 2012;130:879-885.

[5] Moore GF, Littlecott HJ, Moore L. E-cigarette use and intentions to smoke among 10-11-year-old never smokers in Wales. Tob Control. 2014; doi: 10.1136/tobaccocontrol2014-052011.

[6] Bunnell RE, Agaku IT, Arrazola RA. Intentions to Smoke Cigarettes Among Never-Smoking US Middle and High School Electronic Cigarette Users: National Youth Tobacco Survey, 2011-2013. Nicotine \& Tobbaco Res. 2015;17:228-235.

[7] Dockrell M, Morrison R, Bauld L, McNeilli A. E-Cigarettes: Prevalence and Attitudes in Great Britain. Nicotine \& Tobbaco Res. 2013;15:1737-1744.

[8] Hitchman SC, Brose LS, Brown J, Robson D, McNeilli A. Associations between e-cigarette type, frequency of use, and quitting smoking: findings from a longitudinal online panel survey in great britain. Nicotine \& Tobbaco Res. 2015:17:1187-1194

[9] Vancickel AR, Weaver MF, Eissnberg T. Clinical Laboratory assesment of the abuse a liability of an electronic cigarettes. Addiction. 2012;107:1493-1500.

[10] Boström L, Bergström J, Dahlen G. Smoking and subgingival microflora in periodontal disease. J Clin Periodontol. 2011;28:212-219.
[11] Apatzidou DA, Riggio MP, Kinane DF. Impact of smoking on the clinical, microbiological and immunological parameters of adult patients with periodontitis. J. Clin Periodontol. 2015;32:973-98.

[12] Gomes SC, Piccinin FB, Oppermann RV. Periodontal status in smokers and never-smokers: clinical findings and real-time polymerase chain reaction quantification of putative periodontal pathogens. J Periodontol. 2006;77:1483-1490.

[13] Callahan-Lyon P. Elektronic cigarettes: human health effects. Tob Control. 2014;23:36-40.

[14] Benowitz NL. Emerging nicotine delivery products implication for public health. Ann Am Thoracic Soc. 2014;11:231-235.

[15] Polosa R, Caponetto P, Moriaria JB. Efect of eletronic nicotine delivery device (e-cigarette) on smoking reduction cessation: a prospective 6 -month by pilot study. BMC Public Health. 2011;11:786-792.

[16] Cobb NK, Abrams DB. E-cigarette or drug delivery device?, Regulating novel nicotine products. The New Engl J Med. 2011;365:193-195.

[17] Caponetto P, Campagna D, Papale G. The emergining phenomenon of eletronic cigarettes. Expert Review of Respiratory Medicine. 2012;6:63-74.

[18] Etter JF. Electronic cigarettes: a survey of users. BMC Public Health. 2010;58:31-224.

[19] Etter JF, Bullen C. Electronic cigarette: users profile, utilization, satisfaction and perceived efficacy. Addiction. 2011;106:2017-2028.

[20] Inkielewicz-Stepniak I, Santos-Martinez MJ, Medina C, Radomski MW. Pharmacological and toxicological effects of co-exposure of human gingival fibroblasts to silver nanoparticles and sodium fluoride. Int J Nanomed. 2014;9:1677-1687.

[21] Behar RZ, Davis B, Wang Y. Identification of toxicants in cinnamon-flavored electronic cigarette refill fluids. Toxicol In Vitro. 2014;2:198-208.

[22] Willershausen I, Wolf T, Weyer V. Influence of e-smoking liquids on human periodontal ligament fibroblasts. Head Face Med. 2014. doi: 10.1186/1746-160X-10-39.

[23] Gaworski CL, Dozier MM, Gerhart JM. 13-week inhalation toxicity study of menthol cigarette smoke. Food and Chem Toxicol. 1990;35:683-692.

[24] Doolittle DJ, Lee CK, Ivett JL Genetic toxicology studies comparing the activity of sidestream smoke from cigarettes which burn or only heat tobacco. Mutation Research. 1990;240:59-72.

[25] Doolittle DJ, Lee CK, Ivett JL. Comparative studies on the genotoxic activity of mainstream smoke condensate from cigarettes which burn or only heat tobacco. Environ Molecular Mutagen. 1990;15:93-105.

[26] Roemer E, Tewes FJ, Meisgan TJ. Evaluation of the potential effects of ingredients added to cigarettes. Part 3 : In vitro genotoxcity and cytotoxicity. Food and Chem Toxicol. 2002;40:105-111.

[27] Yerger VB. Menthol's potential effects on nicotine dependence: a tobacco industry prspective. Tob Control. 2011;20:29-36.

[28] Villanti AC, Richardson A, Vallone DM. Flavored tobacco product use among U.S. young adults. Am J Prev Med. 2013;44:388-391.

[29] Farley SM, Seoh H, Sacks R. Teen use of flavored tobacco products in New York city. Nicotine \& Tobbaco Res. 2014;16:1518-1521.

Acceptance for editing: 2016-04-28 Acceptance for publication: 2016-05-06

Correspondence address:

Aida Kusiak

Department of Periodontology and Oral Mucosa Diseases

Medical University of Gdańsk

18 Orzeszkowej Street, 80-204 Gdańsk, Poland

e-mail: akusiak@gumed.edu.pl 